\title{
Carbon dioxide retention associated with a humidifier defect
}

Stephen McNulty Do, Lydia Barringer MD, Joseph Browder MD
A case is presented which describes a patient who developed hypercarbia resulting from a defective humidifier. A PuritanBennetl Cascade I humidifier was incorporated into a circle system between the inspiratory dome orwe way valve and the patient. A screw which supports the thermal well to the head of the humidifier was misxing, thereby allowing an intermittent leak to develop in the system. The leak was present when the system pressure dropped to ambient level; however, at pusitive system pressure the leak sealed. This allowed exhaled gases into the inspiratory limb of the circuit unchecked by the inspiratory valve yet when the breathing circuit was occluded at the patient end and submitted to pressures of 20 and $40 \mathrm{~cm} \mathrm{H}_{2} \mathrm{O}$, no leaks were detected. Intraoperatively, $\mathrm{PaCO}_{2}$ was noled to be as high as $68 \mathrm{mmHg}$ just prior to removing the humidifier from the circuit and corrected to $38 \mathrm{mmHg}$ within 15 minutes of removal of the numidifier.

The adverse effects of inhaling dry anaesthetic gases have been described. ${ }^{1,2}$ The potential benefit of reducing postoperative pulmonary complications with humidification of inspired gases has been reported. ${ }^{3}$ A variety of humidification systems are available and despite their advantages, they have been associated with various hazards including risk of infection, increased airway resistance, increased dead space, over-hydration, and a source for leaks or disconnections. Rebreathing may occur in various breathing circuits ${ }^{4}$ and has been reported following a humidifier leak in the fresh gas flow of a Mapleson D modification of the Ayres T-piece. ${ }^{5}$ The following is a case report of a humidifier leak in a circle system that resulted in hypercarbia via an unusual mechanism

\section{Key words}

EQUIPMENT: humidifier; COMPLICATIONS: hypercarbia

From the Department of Anesthesiology, Jefferson Medical College of Thomas Jefferson University, 111 South 11 th Street, Philadelphia, Pennsylvania 19107

Address correspondence to: Dr. McNulty.

\section{Case report}

A 53-year-old, $65 \mathrm{~kg}$ male was scheduled for an exploratory laparotomy for severe necrotizing enterocolitis with multiple enteric fistulae. The patient had a history of pancreatic cancer diagnosed four months prior to admission. Preoperative serum electrolytes, haemoglobin, haematocrit and arterial blood gases were all within normal limits. The patient was brought to the operating room following pre-medication with meperidine $75 \mathrm{mg}$ and atropine $0.4 \mathrm{mg}$ IM.

Prior to the induction of anaesthesia the circle system had been pressure tested by occluding the patient end of the circuit and submitting the circuit to 20 and $40 \mathrm{~cm} \mathrm{H}_{2} \mathrm{O}$ pressure with no additional fresh gas flow and observing no loss of pressure from the system.

Induction and intubation proceeded without difficulty. Anaesthesia was maintained with 40 per cent $\mathrm{O}_{2} / \mathrm{N}_{2} \mathrm{O}$, isoflurane, fentanyl, and pancuronium. An Ohio 30/70 anaesthesia machine was used incorporating a PuritanBennett Cascade I humidifier, between the inspiratory dome valve and the patient, within the inspiratory limb of the circuit. The ventilator used was an Air-Shield Model \#VC20-1, with an upright bellow which ascended during exhalation.

During the second hour of the proccdure the blood pressure and heart rate progressively incrcased from $115 / 80$ to $160 / 90$ and 103 to 148 respectively. The depth of anaesthesia was increased using additional narcotic and increasing the inspired concentration of isoflurane. Urine output, CVP and the patient's temperature were all normal. The peak airway pressure remained constant at $28 \mathrm{~cm} \mathrm{H} \mathrm{H}_{2} \mathrm{O}$, chest expansion appeared unchanged, and there were no auscultatory changes or abnormalities. An arterial blood gas revealed respiratory acidosis: $\mathrm{pH}=7.20, \mathrm{PaO}_{2}=103 \mathrm{mmHg}, \mathrm{PaCO}_{2}=64 \mathrm{mmHg}$. The minute ventilation was increased from $V_{T}=650 \mathrm{ml}$, $\mathrm{f}=10$ to $V_{\mathrm{T}} 700 \mathrm{ml}, \mathrm{f}=14$ and $5 \mathrm{~cm} \mathrm{H}_{2} \mathrm{O}$ PEEP was added. The system was re-checked for leaks. Breath sounds were normal by auscultation and equal bilaterally. There was no apparent obstruction to expiration and a suction catheter passed easily through the endotracheal tube. The $\mathrm{CO}_{2}$ absorbent was fresh with no gross evidence of channeling and the inspiratory and expiratory valves were operating normally. The patient had no history of 
hyperthyroidism or sepsis, was not receiving hyperalimentation and had not received bicarbonate. Although the patient's temperature was not elevated, malignant hyperthermia was considered but not diagnosed due to the paucity of other signs and symptons. A second arterial blood gas was obtained 15 minutes after the ventilation changes: $\mathrm{pH}=7.18, \mathrm{PaO}_{2}=250 \mathrm{mmHg}, \mathrm{PaCO}_{2}=$ $68 \mathrm{mmHg}$. The breathing circuit and humidifier were replaced with a new circuit on the suspicion of a possible problem with the connections of the humidifier to the circle system. Ten minutes following the replacement of the circuit arterial blood gases retumed to normal with $\mathrm{pH}$ 7.36, $\mathrm{PaO}_{2}=253 \mathrm{mmHg}, \mathrm{PCO}_{2}=38 \mathrm{mmHg}$.

After the surgery was completed, the circuit was carefully examined and the only defect discovered was a missing screw that normally secures the thermal well to the top of the humidifier (Figure). When the defective humidifier was incorporated into the circle system, the loose heating assembly resulted in an intermittent leak in the system. However, because of the construction of the humidifier and the relation of the heating assembly to the lid of the humidifier, the leak would become sealed during positive pressure, somewhat like a flap valve mechanism. During expiration, when the system pressure retumed to ambient, the heating assembly would drop, allowing gas to escape around the thermal well and out of the top of the humidifier. This permitted exhaled gases to enter the inspiratory limb of the circuit. The aberrant function of the humidifier could be directly observed using a five litre breathing bag attached to the patient end of the circuit. The amount of gas lost from the system during ventilation was measured by setting $V_{T}=700 \mathrm{ml}, f=14$ and noting that a fresh gas flow of $2.0 \mathrm{~L} \cdot \mathrm{min}^{-1}$ was required to fill the upright bellows during exhalation. Measurement of inspiratory tidal volume using a Wright's respirometer showed no discrepancy between the delivered volume and the volume indicated on the bellows. Pressure checks performed at 5,10 and $15 \mathrm{~cm} \mathrm{H}_{2} \mathrm{O}$ revealed significant leaks a: 5 and $10 \mathrm{~cm} \mathrm{H}_{2} \mathrm{O}$, a very small leak at $15 \mathrm{~cm} \mathrm{H}_{2} \mathrm{O}$, and no leak $>15 \mathrm{~cm} \mathrm{H}_{2} \mathrm{O}$ pressure.

\section{Discussion}

In the case presented, the leak was not initially detected due to a failure to notice the humidifier defect during routine equipment maintenance. The problem might also have been detected if the exhaled gases had been directly measured using a respirometer attached to the expiratory limb of the circuit or if a system pressure check had been performed at $10 \mathrm{~cm} \mathrm{H}_{2} \mathrm{O}$ pressure. Capnography or inspiratory/expiratory carbon dioxide tension measurement would have been helpful in more quickly defining the problem. Also, if the fresh gas flow had been temporarily discontinued, the progressive loss of gas from

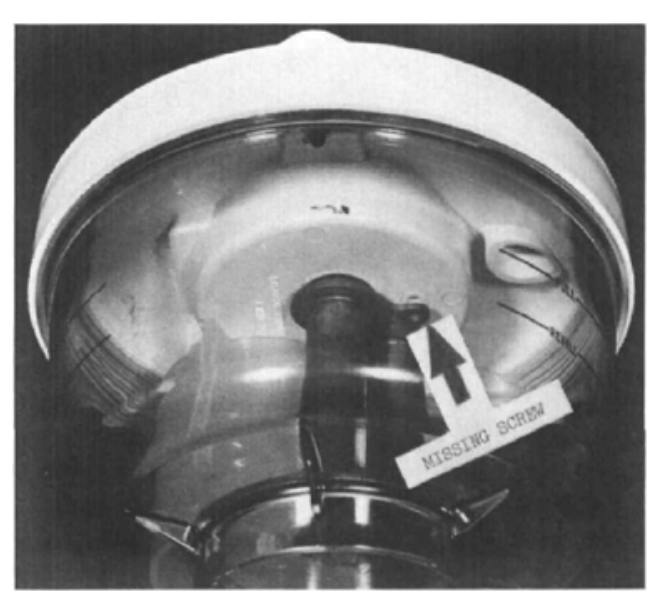

FIGURE Puritan-Bennett Cascade I Humidifier with screw missing on thermal well

the breathing circuit would have resulted in incomplete filling of the ventilator bellows. In the present case, the fresh gas flow ( $5 \mathrm{~L} \cdot \mathrm{min}^{-1}$ ) was sufficient to compensate for gas that may have been lost from the system.

Five other Bennett Cascade humidifiers were tested using a $5 \mathrm{~L}$ breathing bag attached to the patient-end of a circle system in a similar setting to determine whether this might be a recurring problem. With the same screw removed from each of the humidifiers only one partially reproduced the flap valve mechanism. From this evaluation, it was determined that worn, non-compliant rubber seals on the original humidifier were partly responsible for its malfunction. This would also suggest that because of the combination of factors required to reproduce this situation, it is less likely to be encountered in the clinical setting.

Notification of the manufacturer concerning this case resulted in recommendations for careful equipment maintenance and consideration for a lower system pressure check when using this humidifier in an anaesthetic breathing circuit. The measurement of exhaled gases by continuous spirometry would enhance the safety of any anaesthetic circuit. Use of this particular humidifier in our operating room is not common; however, they are widely used with mechanical ventilators such as the PuritanBennett MA-1 volume cycle ventilator. The manufacturer also reported that the possibility of a similar defect occurring in this mechanical ventilator would be small but if it did occur, detection could be easily accomplished by noting a discrepancy between the set volume and the volume measured on the expiratory bellows. 


\section{Conclusion}

This case report re-emphasizes the importance of careful maintenance of all equipment. ${ }^{6}$ It is also meant to point out how specific defects in the Bennett Cascade humidifier may result in significant rebreathing. Although this would seem to be an uncommon problem, it can be difficult to delect in the operating room without the use of capnography, measurements of inspired $\mathrm{PCO}_{2}$ levels, or expiratory spirometry. In the intensive care setting, this problem might be more easily detected in that there would be a discrepancy between the volume set on the ventilator and the volume which returns to the bellows.

\section{References}

1 Chalon J, Loew D, Malebranche J. Effects of dry anesthetic gases on tracheobronchial ciliated epithelium. Anesthesiology 1972; 37: 338-43.

2 Boys $J E$, Howelis $T H$. Hunidification in anaesthesia. $\mathrm{Br} \mathrm{J}$ Anesth 1972; 44: 879-86.

3 Chalon J, Patel C, Ali M et al. Humidity and the anesthetized patient. Anesthesiology 1979; 50: 195-8.

4 Waters DJ, Mapleson WW. Rebreathing during controlled respiration with various semi-closed anaesthetic systems. Br J Anaesth 1961; 33: 374-81.

5 Nimocks $J A$, Modell JH. Perry PA. Carbon dioxide retention using a humidi fied non-rebreathing system. Anesth Analg 1975; 54: 271-3.

6 Cooper JB, Newbower R, Long CD, MCPeek B.

Preventable anesthesia mishaps - a study of human factors. Anesthesiology 1978; 49:399-406.

\section{Résumé}

On présente un cas qui décrid un patient chez lequel s'est formé une hyperarbie résultant d'un humitlificateur défectueux. On avait incarporé un humidificateur Puritan-Bennett Cascade I dans un circuit en cercle entre la valve inspiratoire unidirectionmelle et le patient. L'absence d'une vis supportam le puits thermique du sommet de l'humidificateur permettait la formation d"une fuile intermittente dans le circuit. La fuite étai présente quand la pression du circuit s'affaissait au niveau ambiant et elle était obturée quand la pression du circuit était positive. De celte façon, les gaz expirés pouvaient entrer dans la partie inspiratoire du circuit qui n'étail pas mis en échec par la valve inspiratoire néanmoins lorsque le circuit était obstrué du côté du patient et soumis d̀ des pressions de 20 à $40 \mathrm{~cm}$ de $\mathrm{H}_{2} \mathrm{O}$. on me pouvail déceler aucune fuite. En période intraopératoire. on a observé que la $\mathrm{PaCO}_{2}$ s'élevait jusqu' à $68 \mathrm{mmHg}$ juste avant de retirer thumidificateur du circuit et revenait d $38 \mathrm{mmHg}$ dans les 15 minutes après avoir enlevé $l$ 'hunidificateur. 